\title{
THE BRIDE AN THE WIDOW: OTHER METAPHORS OF LIFE AND DEATH IN IN MEMORIAM
}

\author{
Brunilda Relehmann Lomoe
}

Basil Willey in More Nineteenth Century Studies: a Group of Honest Doubters points out several reasons why the conclusion of In Memoriam is quite appropriate. Firstly he says that since Hailan had been engaged to one of Tennyson's sisters, the wedding of Cecilia Tennyson to Edmund Lushington enabled the poet to finish the series of lyrics in a mood of hope and rebirth and to turn his thoughts to the future. Second, because in the conclusion of In Memoriam Tennyson links the marriage and its future offspring with the evolutionary drift of the elegy, with its thought of em:bryonic development and with he Victorian dream of progress and a better race. ${ }^{1}$ Besides Willey, Clyde de L. Ryals also ocnsiders the Epilogue appropriate because it ties the various themes of the elegy together. 2

Yet there are critics like Carlisle Moore who do not accept Willey's interpretation of In Memoriam as a "triumphal journey from doubt to faith" or who llikewise may question. E. D. H. Johnson's affirmation that the mood in the elegy progresses from despair to assertion of faith. " But neither Moore nor Paull F. Baum, who says that the language used in the Prologue (the last section written) is still a language of doubt and not of faith, question the hopeful tone of the conclusion of the elegy. "

That hope is suggested at the end of In Memoriam is unques. tionable. However no critic has tried to concentrate on and to explore the development of the images of the widow and of the bride throughout the elegy in an attempt to find out how responsible they are for the hopeful tone of its conclusion.

1 WILLEY, Basil. More Nineteenth Centrury stuides: a group of honest doubtero. New York. Harper \& Row, 1966. n. 105.

2 RYALS, Clyde de L. heme and symbol in In Memoriam. In: TENNYSON, Alfred. In Memorinm. Ed. Robert R. Rosy. New York. Norton, 19i3. p. 242.

a Moore, Carlise. Faith, Doubt, and Mystical Exnerience. In: TENNYSON, p. 179. JOHNSON, E. D. II. In Memoriam: the way of the poet. In: TENNYSON, p. 219.

1 BAUM. Paull F. Some deficiencies of In Memoriam. In: TENNYSON, p. 200. 
This idea had its origin in articles written by Jerome Buckley and John D. Rosenberg. "The former explains that the unity of the poem depends more on the recurrence of imagery to wich Tennyson attaches particular meaning, and he shows how the ima. ges of darkness and light, night and day provide a "compellıng tension of opposites wich are the correlatives of life and death, assent and denial - until at last, as in the climatic ninety-fifth lyric," the polarities are "reconciled in a mystic half light "in. Both critics demonstrate how the movement of the poem is from death to life, from darkness to light. "The only critic who gives some importance to metaphors like "widow'd race" and who relates them to the Epilogue seems to be Rya!s. He explains the symbolic situation of the bride standing on tombstones in the conclusion of the foem and how the Earthiy Paradise is united with the Heaveniy Fóradise in the Epilogue. ${ }^{S}$ He does not follow, however, the development of the images of the widow and the bride wich side by side with the images of darkness and light, night and day are also symbolic of death and life throughout the elegy. This essay therefore also attempts to establish a connection between the progress of tirese images as they appear in the lyrics in the order in wich they were published and according to their date of composition (whenever this information is available), besides trying to show how they Evolve in the elegy and how hesponsible they are for its final mood of hope.

Images of widowhood and/or of brides appear in at least twelve sections of In Memoriam: 9, 10 13, 17, 40, 59, 84, 85, 90, 97, 98,99 , and in the Epilogue. These sections are, generally speaking, composed and published in the same order, although we know that Tennyson did not arrange all his lyrics for publication in their order of composition.

Section 9 is dated October 6, 1833 in J. M. Heath's Commonplace Book. W. F. Rawsley's Tennyson 1809-1909, the trial issue of the Memoir, and Hallam Tennyson's statement in the Eversley Edition confirm its early date of composition - within two months

1. BUCKLEY. Jerome. In Memoriam: The way of the soul. 1833-1850. In: TENNYSON, n. 228. ROSENBERG. John D. The two kingloms of In Memoriam. In: TENNYSON. n. 206.

b. EUCKLEY, p. 229.

7 BUCKLEY, p. 230 ; ROSENBERG. D. 213.

8 RYALS, p. 243.

9 MATTES, Eleanor B. Chronolory of In Memoriam. In: TENNYSON, p. 139. The dates sugrested by Mrs Mattes have been checked axsinst Robert H. Ross's commentarice on the chronolory of In Memoriam. 
cf Arthur Hallam's dezth. According to Eleanor B. Mattes, sections 10 and 13 were also written in 1833 because of their reference to the ship wich was to bring Halam's remains back to England. ${ }^{9}$ In section 17, the poet hails the ship, and, since Tennyson was only informed about its arrival on December 30,1833 , this section was probably written in 1834. There is no evidence for the composition of section 40, but the thought expressed in lines 17-20 indicates Tennyson's acquaintance with Isaac Taylor's Physical Thoory of Another Life wich appeared in 1836. This section also seems to precede the questioning resulting from Tennyson's reading of Lyell's Geology in 1837. Section 40 was therefore probably written in 1836. Mrs. Mattes makes no reference either to section 59 or to section 84 . Section 85 was, according to external evidence, one of the first sections written (in 1834) but it was altered and lengthened after 1940. Section 90 was written before 1845 but there is no internal or external evidence to determine its exact date of composition. There is no reference to the composition of section 97. Section 98 is recorded as being written in 1836 because it is addressed to Charles Tennyson and makes reference to this approaching wedding trip after his marriage on May 24, 1836. Section 99 was written the same year, before Tennyson and his family moved from Somersby. Finally Mrs. Mattes soys that the Epilogue was written between December 1844 and the summer of 1845 even though the marriage of Cecilia. Tennyson to Edmund Lushington took place on October 10, 1842. Her argument is that Lushington first saw the Epilogue in the summer of 1845, and, since Tennyson had spent August and September of the previous year with his sister and brother.in-law, he would not have failed to show it to Lushington were it already written. Besides that, there is clear influence of Vestiges of Creation in the Epilogue and the book was ordered by Tennyson at the end of 1844 .

The apprroximate order of composition of lyrics 9, 10, 13, 17, $40,59,84,85,90,97,98,99$ and of the Epilogue seems to be: lyrics 9, 10, and 13 in 1833; lyric 17 and a shorter version of lyric 85 in 1834; lyrics 40,98, and 99 in 1836; lyric 90 before 1845, and the Epilogue by 1845. There is no reference to lyrics 59,84, and 97. Since In Memoriam deals with Tennyson's grief at the loss of ris young friend Arthur Hallam and with the poet's recovery, it seems rather important to be able to refer to the date of composition of these sections in which the images of the widow and cif the bride occur. Since there is no evidence concerning the composition of some sections, we will try to associate them (lyrics 59, 
84, and 97) with others in wich the poet develops a similar idea. We may also come to realize that knowledge of the date of composition of some of these sections is not essential to the development of the imagss.

An outline of the subject of the twelve sections with its images of widowhood and bridal looks like this:

Lyric

- ship which was to bring Hallam's remains back to England - "widow'd race"

10 (similar subject) sailor returning to his wife

13 (similar subject) widower who dreams of his wife

17 hail to the ship which brought Hallam's remains "widow'd race"

40 maid on her wedding day and in her happily married life - "widow hour"

1833

1834

1836

84 (related to section 40) Tennyson's happy involvement in Hailam's imaginary household - "cy. press" and "orange flower"

59 Sorrow personified as wife and lovely bride (related to section: 3)

85 addressed to Edmund Lushington -

Tennyson's warmth towards a new friendship "widow'd heart"

revised

and enlarged

after

1840

90 the dead who would find a hard welcome if they rose (related to sections 91, 92, 93, 94, and 95)

97 Tennyson thinks of his spirit as that of a wife

98 addressed to Charles Tennyson about his wedding trip up the Rhine - "birth" and "bridal"

99 the second anniversary of Hallam's death "bridal" and "birth"

Lyric 9, the first one in which the image of the widow occurs, reads like a prayer for the ship which will bring Halam's remains back to England. The directing images in this sections are darkness and light, and the fair ship is adressed as the guardian of Hallam's "holy urn" through the darkness of the night until

Phosphor, bright

1n TrMaYsoN, p. 9. All the subsequent references will be to this edition and will be documented in the body of the paper. 
As our pure love, thro' early light

Shall glimmer on the dewy decks.

Sphere all your lights around, above;

Sleep, gentle heavens, before the prow;

Sleep, gentle winds, as he sleeps now,

My friend, the brother of my love;

My Arthur, whom I shall not see

Till all my widow race be run;

Dear as the mother to the son,

More than my brothers are to me. ${ }^{10}$

The last stanza emphasizes the sorrow that accompanies the poet as one of a widowed race - as one who has lost the com. panion of his choice. It also suggests the transient condition of man on rith. Returning to the line "Till all my widow race be rum" it seems evident that Tennyson hopes to see his friend again. This hope may be only half-conscious on the part of the poet, but the negative connotation attached to life on earth seems to impart an orthodox Christian flavor to life after death.

A variation of the image of the bride appears for the first time in section 10. As light again stands in contrast to darkness in this section, the sailorùs wife to whom he returns stands in contrast to the poet who imaginatively awaits a "dark freight, a vanished life" ('.8). Both the wife and the poet wait for loved ones; one is aiive, enveloped by light; the other is dead, enveloped by darkness.

I hear the noise about thy keel;

I hear the bell struck in the night:

I see the cabin-window bright;

I see the sailor at the wheel.

Thou bring'st the sailor to his wife,

And travell'd men from foreign lands;

And letters unto trembling hands;

And, thy dark freight, a vanish'd life. (Il. 1-8)

In this section, as in most of the sections in which Tennyson expresses his relationship with Hallam in marital terms, Tennyson's position is compared to that of a wife. In section 13 the opposite sccurs. This time the description is of a widower who while asleep sees the form of his departed wife, but when his arms try to reach her, she is not by his side.

Tears of the widower, when he sees

A late-lost form that sleep reveals, 
And moves his doubtful arms, and feels

Her place is empty, fall like these; (II. 1-4)

Feelings of intense loss, emptiness and silence permeate this lyric, and, at the very end of stanza 1 and in stanza 2, the poei establishes a parallel between the experience of the widower and his own at the loss of his friend Hallam. Tears, says Tennyson,

Wich weep a loss for ever new

A void where heart on heart reposed;

And, where warm hands prest and closed,

Silence, till I be silent too. (II. 5-8)

There is a perfect correspondance between the physical contact the widower seeks and the touch of Hallam's warm hands which Tennyson remembers, because neither one can be any more. Yet it is hard for Tennyson to accept the loss, and he wonders if his suffering is not merely a nightmare and if the ships bring merely merchants' large bundles of goods. Both the widower and Tennyson can be "happier" when they are somehow removed from reality. The widower is happier in his dream because his wife is alive in it, Tennyson is happier in his flights of fancy, because he does not have to face his friend's death in them. Tennyson's "pretence" that the sails bring only their usual cargo reveals that he is far from accepting Hallarn's death. If he cannot face it, how can he accept it? Tears, continues Tennyson,

Which weep the comrade of my choice,

An awful thought, a life removed,

The human-hearted man I loved,

A Spirit, not a breathing voice.

Come Time, and teach me, many years,

1 do not suffer in a dream;

For now so strange do these things seem,

Mine eyes have leisure for their tears;

My fancies time to rise on wing,

And glance about the approaching sails,

As tho' they brought but merchants' bales,

And not the burthen that they bring. (II. 9-20)

Among the lyrics which were written in 1833, lyrics 9, 10, 11, 12 , and 14 form a urity with section 13 by their common reference to the ship which was to bring Hallam's body. Besides the similar subject and the use of similar metaphors of life and deatin in these lyrics, we find in sections 10 and 14 , as in section 13, 
the recurrent image of hands which can no longer be touched. The memory of the touch of Hallam's warm hands becomes an emblem of being alive, of sharing Tennyson's love, and of communing with the poet's soul. That these hands should now be "in contact" with cold and irresponsive tangles and shells, as presented in section 10 , is a thought wich upsets the poet.

$$
\text { O to us, }
$$

The fools of habit, sweeter seems

To rest beneath the clover sod,

That takes the sunshine and the rains,

Or where the kneeling hamlet drains

The chalicc of the grapes of God;

Then if with thee the roaring wells

Should gulf him fathom-deep in brine.

And hands so often clasp'd in mine,

Should toss with tangle and with shells. (II. 11-20)

Section 14, on the other hand, tells how the poet, at the news of his friends's arrival, would not find it strange if going to the port he should see Hallam stepping down the plank with the other passengers and if Hallam

Should strike a sudden hand in mine

And ask a housand things of home. (11. 11-12)

This section reveals one of Tennyson's most intense desires which recurs throughout the initia! sections of the elegy - that the cieath of his friend be but a nightmare from which the poet will be awakened. It can also be explained as a means of escaping suffering by flights of imagination. The other two sections $(11$ and 12) also written in 1833 refer to the ship carrying Hallam's remains and demonstrate how varied is Tennyson's mood soon after he hears about his friend's death.

In section 11, where Tennyson's "deeper anguish" seems to fall like the tide, he expresses the predominance of "calm despair." The morning is calm; there is calm and peace in the high wold and on the dews; there is colm on the great plain, calm and deep peace in the air, calm on the seas, and in the remains of his friend -- "And dead calm in that nable breast" (1. 19). Yet the poet's srief does not find a perfect parallel in the calmness of nature. The first and second lines of the section read:

$$
\text { Calm is the morn witthout a sound, }
$$


Calm as to suit a calmer grief.

And later he says:

And in my heart, if calm at all,

If any calm, a calm despair. (II. 16-16)

But we do not find any of this "calm despair" in section 12. iennyson's eyes and mind like the dove fly away to more distant skies and sails:

Lo, as a dove when up she springs

To bear thro' Heaven a tale of woe,

Some dolorous message knit below

The wild pulsation of her wings;

Like her I go; I cannot stay;

I leave this mortal ark behind

A weight of nerves without a mind

And leave the cliffs, and haste away

O'er ocean-mirror rounded large,

And reach the glow of southern skies

And see the sails at distance rise, (II. 1-11)

But reality's dark dream is too intense to be dismissed so easily and Tennyson remains "weeping on the marge" asking questions formulated by his despair at the loss of his dear friend and about the ultimate meaning of life:

'Comes he thus, my friend?

is this the end of all my care?'

And circle moaning in the air:

"Is this the end? is this the end?" (II. 13-16)

As we can see, even in this group of lyrics which are supposed to have been written in the same year, Tennyson's grief reveals itself in several different forms: through denial, through repression, through escape, through expansion, and so on. We can thus see that the poet is far from accepting his friend's death, and that the image of the widow reinforces Tennyson's feelings of emptiness, void, and loneliness.

Johnson, considering the three Christmas seasons as chronola gical points of division of the poem, says that In Memoriam falls into four parts the dominant mood progressing from an initial despair over Hallam's death (1-27), through a period of philosophic doubt (28-77), to nascent hope (78-103), and finally to a confident assertion of faith (104-131). ${ }^{11}$ 
We should bear in mind, nonetheless, that although we may qualify the dominant mood of a group of poems, the mood of each of the lyrics is not progressively consistent. Before section 28 Tennyson has already expressed philosophic doubt as we have seen in section 12. While in section 13 feelings of utter loneliness and emptiness predominate and the poet makes no reference to a possible union with Hallam after death, in lyric 9 he has suggested such hope and he returns to the same thought in section 17. Note the similarity between lines 17 and 18 of section 9:

My Arthur, whom I shall not see

Till all my widow'd race be run;

and lines 19 and 20 of section 17 :

The dust of him I shall not see

Till all my widow'd race be run.

Although the image "widow'd race" imparts a mournful tone to lyric 17 and enhances the presence of death in life, the poet's hail to the ship which brings Hallam's remains is expressed in hearty terms. The fact that one Tennyson loved and still loves has retuned to his native country is reason enough for this "welcome". Besides that, we cannot help asociating Tennyson's act of blessing the ship with the Ancient Mariner's act of blessing the creatures of the ocean. Tennyson's blessing "like a line of light, / Is on the water day and night / And like a beacon guards thee home" 111 . 10-12). Yet while the Ancient Mariner's blessing is a sign of innate goodness towards life, Tennyson's is a sign of innate goodness and furthermore an expression of the delicacy and intensity of his care for lifeless remains. The poet's feelings of despair or of calmer grief cease to exist, and give place to a hearty welcome:

Thou comest, much wept for: such a breeze

Compell'd thy canvas, and my prayer

Was as the whisper of an air

To breathe thee over lonely seas.

For 1 in spirit saw thee move

Through circles of the bounding sky,

Week after week: the days go by:

Come quick, thou bringest all I love.

Henceforth, wherever thou may'st roam,

My blessing, like a line of light,

is on the waters day and night,

11 JOHNSON, D. 210. 
And like a beacon guards thee home.

So may whatever tempest mars

Mid ocean, spare thee, sacred bark;

And balmy drops in summer dark

Slide from the bosom of the stars.

So kind an office hath been done,

Such precious relics brought by thee; (II. 1-18)

The image of the widow and of the bride appear together for the first time in lyric 40 . The imaginary marriage Tennyson describes in this section suggests an immediate relationship with the marriage of Emily Tenryyson to Arthur Hallam (which did not take flace because of his early death) even though the poet does not refer directly to it. The poet joins in the first stanza of the poem an image of sadness and death with an image of happiness and life:

Could we forget the widow'd hour

And look on spirits breathed away,

As on a maiden in the day

When she first wears her orange flower! (II. 1-4)

Tennyson then gces on to describe the young wife's last leave from home, her ambivalent feelings about it, her father's and her mother's concern, and her future role as a mother as well as a linking element between the generations:

When crown'd with blessing she doth rise

To take her latest leave from home,

And hopes and light regrets that come

Make April of her tender eyes;

And doubtful joys the father move,

And tears are on the mother's face,

As parting with a long embrace

She enters other realms of love;

Her office there to rear, to teach,

Becoming as is meet and fit

A link among the days, to knit

The generations each with eacr, (II. 5-16)

But, breaking the flow of the poet's imagination, the image of Hallam returns and, like Worc'sworth at the end of "She Dwelt Among the Untrodden Ways," Tenmyson says:

Ay me, the difference I discern'. (1. 21)

To say that Tenriyson is establishing a contrast between the 
bride of his imagination and Emily's situation at the time he was writing the section is to affirm something which is not stated in the poem; we cannot help, however, establishing the connection. The poingnant contrast between what could have been and what is is made by implication. While we read about the happy visits of the young bride to her parent's home, while we hear her boasting about her baby, we picture the constant sad loneliness of Emily at her parent's home and her empty arms. By association with Wordsworth, the whole difference lies in the fact that a loved one is dead.

The image of the baby which appears in lyric 40 will reappear in later lyrics and in the Epilogue. The baby is the embodiment cf the soul that is drawn "from out the vast / And strike its being into bounds" (Epilogue II. 123-124) when the young bride 'enters cther realms of love" (1. 12). Yet, so far the baby is only something to boast about and a link between past and future generations.

At the end of secion 40 , reality wins again with the return of the image of the hands which suggest the parting of the two friends and the different realms of existence inhabited by each:

But thou and 1 have sraken hands,

Till growing winters lay me low;

My paths are in the fields I know.

And Thine in undiscover'd lands. (II 29-32)

A further elaboration on the same subjetc of an imaginative marriage is found in section 84 The presence of death is again brought about by the cypress, and the idea of love and life by the orange blossoms:

But that remorseless iron hour

Made cypress of her orange flower,

Despair of Hope, and earth of thee. (II, 14-16)

The reference to Emily and Hallam is now direct and their, imagined children, like Lamb's dream-children, babb!e "Unc' $e^{\text {" on }}$ Tennyson's knee. They are not only the embodiment of the love between Emily and Hallam, but also, by kinship, a union of the blood of the two frierids:

I see thee [Hallam] sitting crown'd with good

I: Bee Christopher RICK'S commenta on Tennyson's homosexuality in Tennjuon. Nev York, Collier. 1972. p. 214-20. 
A central warmth diffusing bliss

In glance and smile, and clasp and kiss,

On all the branches of thy blood;

Thy blood, my friend, and partly mine;

For now the day was drawing on,

When thou should'st link thy life with one

of mine own house, and boys of thine

Had babbled "Uncle" on my knee; (II. 5-13)

The thought that the poet will see Hallam again after his own death expressed in sections 9 and 17 receives further development in this section. It is also quite interesting to notice the egotistical aspect of Tennyson's love for Hallam. ${ }^{12}$ It is his and Hallam's companionship on earth which is always remembered or dreamed of; it is the union of his and Hallam's spirit after death which the poet seeks. Emily's love and sorrow remain as faint shadows of Tennyson's and lyric 84 is one of the few lyrics in which some importance is given to her, but merely as an extra link between the foet and Hallam. Tennyson prefers again to imagine what could have been rather than to look upon what is. He pictures himself as the uncie who wou'd meet his nephew's least desires, who would be an honored guest and partner at Hallam's prosperous home until time would bind their spirits as it had bound their lives and they would be taken as one single soul by Christ.

I see myself an honour'd guest

Thy partner in the flowery walk

of letters, genial table-talk,

Or deep dispute, and graceful jest;

While now thy properous labour fills

The lips of men with honest praise,

And sun by sun the happy days

Descend below the golden hills

With promise of a morn as fair;

And all the train of bounteous hours

Conduct by paths of growing powers,

To reverence and the silver chair;

Till slowly worn her earthly robe, Her lavish mission richly wrought, Leaving great legacies of thought,

Thy spirit should fail from off the globe; 
What time mine own might also flee,

And link'd with thine in love and fate,

And, hovering o'er the dolorous strait

To the other shore involved in thee,

Arrive at last the blessed goal,

And $\mathrm{He}$ that died in Holy band

Would reach us out the shining hand,

And take us as a single soul. (II. 21-44)

However, as in many lyrics in which the poet gives expression to his fancy, at the end of section 84 he is pulled back down to earth or loses grasp of the children, who, like Alice and John,

gradually grew fainter to my view, receding, and still receding, till nothing at last but two mournful features were seen in the uttermost distance, which without speech, strangely impressed upon me the effects of speech: 'We are not of Alice, nor of thee, nor are we children at all' 13

Who are the boys? Whose house is it in wich Tenmyson sees himself as an honored guest? Whose blood will be bound to his? Whose espirit will be taken in with his by Christ as a single c.ne? Tennyson then asks:

What reed was that on which I leant?

Ah, backward fancy, wherefore wake

The old bitterness again, and break

The low beginnings of content. (II. 45-48)

The use of the image of the bride in lyric 59 does not seem to be of great importance to the development of the marital imagery in relation to the poet's grief because the image does not stand as a parallel or as a contrast to his sorrow. This lyric was only inserted in the fourth edition of In Memoriam and was designed as a parallel to section 3. "Wife" and "bride" ore, in section 59, personifications of Sorrow. The editor Robert Voss explains that

Sorrow is addressed in each poem [3 and]. In section 3, Sorrow declares the universe to be pointless and futile and thus strikes the prevailing tone for roughly the first half of the poem. Here [section 59], however, Sorrow is addressed more hopefully (in a marriage metaphor), which suggests the proper tone for 
the speaker's recovery in the second half of In Momoriam. ${ }^{14}$

Section 59, in comparison with most of the other lyrics, sounds rather artificial. Its composition is neither the result of a felt experience nor of a deep desire as most lyrics are.

Tennyson's decision to include lyric 90 where he does seems somenwhat of a puzzle when we consider the lyrics which precede it. Among sections which reveal nascent hope (e.g., lyric 85), after the second Christmas in which the poet seems to have attained some kind of consolation, after he re-affirms that indeed "It is better to have loved and lost, / Than never to have loved at all" ('yric 85, 11. 3-4; cf. lyric 27, II. 15-16), after spring return exuberant and even pain begins to espace him: "And I- my harp would preclude woe - / I cannot all command the strings: / The glory of the sum of things / Will flash along the chords and go" (lyric 88, 11. 9-12), Tennyscn cries out for Hallam's return.

Tennyson imagines dead people resuming their lives and not inding a warm welcome from their wives and children. Even those wives and children who talk warmly of those who are gone, would not welcome their departed loved ones because now the wives are in someone else's hands and the heirs ar fighting for the lands:

That could the dead, whose dying eyes

Were closed with wail, resume their life,

They would but find in child and wife

An iron welcome when they rise:

Twas well, indeed, when warm with wine,

To pledge with them with kindly tear,

To talk them o'er, to wish them here,

To count their memories half divine;

But if they came who past away, Behold their brides in other hands;

The hard heir strides about their lands,

And will not yield them for a day. (II. 5-16)

Tennyson, on the contrary, like a loving wife who remains faithful to her departed husband and does not find consolation

13 LAMB, Charleg. Dream-Children: a reverie. In: ANDERSON, George K. * BUCKER, Wiliam E., eds. The literature of Enzland. Atlanta. Scott, Foresman, 1968. v. 2. D. 446.

14 TENNTSON, p. 37. 
for her loss, cries out:

Ah dear, but come thou back to me:

Whatever change the years have wrought,

I find not yet one lonely thought

That cries out against my wish for thee. (11. 21-24)

When we consider, nonetheless, the lyrics which follow and form a unit with section 90 leading to the climactic section 95, we see how appropriate its position is. With the contrast between the wives and children who do not truthfully want their husbands and fathers to return and Tennyson's almost embarrassing cry for Hallam's return, the poet begins a crescendo movement which culminates in the mystical union related in section 95. From the intense desire for Hallam's return (lyric 90) to the mystical union with Hallam, Tennyson's "invites" his friend's spirit to come "like a finer light in light" (lyric 91, 1. 76); then he doubts the validity of a vision of his friend as a psychic trick (lyric 92); and then he Iries to convince himself that he will not see Hallam (lyric 93) until one summer night, after each member of the poet's family goes to sleep and light after light goes out in the house, Tennyson experiences a momentary but fully satisfactory union with the spirit of Hallam. The experience is like a marriage of souls after which hope is again possibie. Although it is impossible to determine the date of composition for section 95, the experience occurred in 1837 at the latest, before Tennyson moved from Somersby. Before that, lyrics 98 and 99 were already written and the image of the widow had already disappeared to give place to the events of bridal and birth in both poems.

Sections 98 and 99, according to Tennyson's arrangement of the lyrics, are the two last sections in which the image of the icride occurs before the Epilogue. Section 98 deals with Charles Tennyson's wedding trip and section 99 deals with the second anniversary of Hallarn's death. Section 99 should precede section 98 if the poet did not take liberties with his chronology, because Chorles Tennyson's wedding took place in May 1836 and the second enniversary of Hallam's death, on September 15, 1835. Besides this change, Tennyson writes section 98 as if the event described took place in the summer preceding the autumn of the anniversary.

To say, however, that Charles Tennyson's wedding trip is the subjetc of section 98 is not an accurate observation, because his wedding trip is but the starting point of the lyric: 
You leave us: you will see the Rhine

And those fair hills I sail'd below,

When I was there wiht him; and go

By summer belts of wheat and vine

To where he breathed his latest breath,

That City. (II. 1-6)

The poet's brother's trip up the Rhine reminds Tennyson of o time that he and Hallam had gone that way. Furthermore it reminds the poet of the fateful city in wich Hallam died - Vienna:

All her splendour seems

No livelier than the wisp that gleams

On Lethe in the eyes of Death.

Let her great Danube rolling fair

Enwind her isle, unmark'd of me:

I have not seen, I wil not see

Vienna; rather dream that there,

A treble darkness, Evil haunts

The birth, the bridal; friend from friend

Is often parted, fathers bend

Above more graves, a thousand wants

Gnarr at the heels of men, and prey

By each cold hearth, and sadness flings

Her shadow on the blaze of kings: (11. 6.19)

But counteracting Tennyson's imaginative picture of the dreadful eity lies Hallam's own description in the poet's memory:

And yiet myself have heard him say,

That not in any mother town

With statelier progress to and fro

The double tides of chariots flow

By park and suburb under brown

Of lustier leaves; nor more content,

He told me, lives in any crowd,

When all is gay with lamps, and loud

With sport and song, in booth and tent, Imperial halls, or open plain;

And wheels the circld dance, and breaks

The rocket molten into flakes

of crimson or in emerald rain. (11. 20-32)

The bridal mentioned in this section neither bears any connection with the poet's grief nor is being used as a contrast to the 
poet's loss. This image is no longer associated with widowhood either. Now it is associated with birth or life. Bridal and birth are events pregnat with hope and happiness. They have to be preserved from the evil and destructive forces in the city. They embody !arger connotations than those related directly with Hallam's death or Tennyson's sorrow (even though in line 13 the separation of friends recalls Tennyson's friendship with Hallam which was severed ty his sudden death). It seems that now the poet is able to look at things as they really are and talk about his friend as a friend and not as a beloved hushand taken away from him by death. The s. me is true in section 99.

The dawn of the reccurrently fateful day with its thick voices of birds and lowings oft he herds, in section 99, makes the puet say:

Day, when I lost the flower of men;

Who tremblest thro' thy darkling red

On yon swoll'n brook that bubbles fast

By meadows breathing of the past,

And woodlands holy to the dead;

Who murmurest in the foliage eaves

A song that slights the coming care,

And Autumn loying here and there

A fiery finger on the leaves;

Who waker,est with thy balmy breath

To myriads on the genial earth

Memories of brical, or of birth,

And unto myriads more, of death. (11. 4-16)

As we can see in the last stanza, Tennyson refers to memories "remembered" not to memories "felt." Now he refers to birt, bridal, and death es the major events in the cyclical journey of man on earth using proper names and not metaphors like the ones we find in section 72 - the lyric written on the occasion of the first anniversary of Hallam's death, in wich images of light and darkness stand for life and decth. The rage expressed in section 72 has Elso been subdued by lyric 99 . The day of the first anniversary of Hallam's death becomes "guilty" and marked by unconcern. Its shame is only hidden by the approaching night:

Day, mark'd as with some hideous crime,

When the dark hand struck down thro' time,

And cancell'd nature's best: but thou,

Lift as thou may'st thy burthen'd brows

Thro' clouds that drench the morning star 
And whirl the ungarner'd sheaf afar,

And sow the sky with flying boughs,

And up thy vault with roaring sound

Climb thy thick noon, disastrous day;

Touch thy dull goal of joyless gray,

And hide thy shame beneath the ground. (11. 17-28)

The conclusion of section 99 bears a completely different tone. Although the poet is still depressed by the memory of that fateful day, he seems to have come to terms with the existence of death as an inevitable event which has to be faced and accepted. These are the final lines of section 99:

$O$ wheresoever those may be,

Betwixt the slumber of the poles,

To day they count as kindred souls;

They know me not, but mourn with me. (II. 17.20)

Lyric 97, one of the last two remaining lyrics in which the mage of the wife occurs (the other being lyric 85, written in 1834 but enlarged and revised after 1940, in which the image of the widow occurs) describes a domestic idyll, and Tennyson refers to his spirit as that of a wife. The major character in the domestis idyll is a simple girl who canot understand her husband's ways and occupations yet loves him no matter what people say. Tennyson is certainly re-emphasizing, with the young wife's devotion and simplicity, what he mentioned about himself in the last stanza of section 79:

But he [Hallam] was rich where I was poor,

And he supplied my want the more

As his unlikeness fitted mine. (II. 18-20)

And Tennyson sees, in the deep love of the couple, his own love for Hallam delineated:

Two partners of a married life -

I look'd on these and thought of thee

In vastness and in mystery,

And of my spirit as of a wife.

The use of the image of the wife referring to Tennyson's feelings towards Hallam seems to indicate that this section was written during a period in which acceptance was not yet possible and that the intensity of the poet still speaks through marital metachors.

It may seem odd that Tennyson has kept the image of the 
widow in a lyric wich was altered after 1840 , but when we see how this metaphor is used is seems quite appropriate. It is proper because, unlike its use in other lyrics as a symbol of death in life or as a contrast between the feelings of the poe: as a widow and the joyfulness of the bridal, in section 85 the expression "widow'd heart" is used almost as an apology for what follows in the lyric. What follows is the expression of a desire for another emotional involvement in life. Since the enlarged version of section 85 was adressed to Edmund Lushington, it is clear that "another living breast" refers to his new friend who will become his brotherin-law some years later.

My heart, tho' widow'd, may not rest

Quite in love of what is gone

But seeks to beat in time with one

That warms another living breast. (II. 113-16)

Indeed the marriage of Cecilia Tennyson to Edmund Lushington becomes the central event in the Epilogue. We know that Cecilia is not the only membrer of the Tennyson family who gets married and whose marriage is mentioned in the elegy; Charles Tennyson's also is. We way therefore wonder why Tennyson chose Cecilia's and not Charles' wedding as the concluding event in In Memoriam. There seem to be at least two reasons for this choice: first, Charles marriage took place only two years and some months afeter Hallam's death, when perhaps the poet's recovery was not yet complete and his grief not completely exhausted; second, because only with Cecilia's marriage does the event that was planned to take place about a. decade before seem to become a reality. Cecilia's wedding is in a way a consummation of Emily's. The kinship between the bride and the poet, and the friendship between him and the groom, transform Cecilia's marriage into the ideal event for the conclusion of the elegy.

Some may also question whether we should not refer to the images of the bride and of the widow as marriage metaphors instead of as metaphors of life. Lyrics 98, 99, and the Epilogue seem to give an answer to this question. The bride, from lyric 98 $\mathrm{cn}$, is never dissociated from the image of birth. Therefore, as the widow was symbolic of death, the bride becomes symbolic of life. Marriage becomes, as Tennyson himself has suggested, a birth Into other realms of love. One's span of life is marked, therefore, by the birth and death of love - not the capacity to love, but by love as represented by the appearance and the death of a 
loved one. Happiness and companionship are gained at the birth of love, sorrow and loneliness are "gained" at its death.

Besides that, the future infant in the Epilogue is no longer a dream child or someone the young mother boasts about. The emphasis now lies in the real consummation of the married couple's love and the baby becomes the real embodiment of that love. He becomes, in addition, representative of scientific findings, like the embryonic development of the fetus, and furthermore of the Victorian dream of progress and a better race, because he is no longer a mere link between the generations, but a link between the past generations and

the crowning race

Of those that, eye to eye, shall look

On knowledge; under whose command

Is Earth and Earth's, and in their hand

Is Nature like an open book;

No longer half-akin to brute,

For all we thought and loved and did,

And hoped, and suffer'd, is but the seed

Of what in them is flower and fruit; (11. i28-36)

We are not trying to suggest, on the other hand, that Tenneyson forgets or neglects to refer to Hallam's death in the Epilogue. Hallam is the subject of the opening and closing stanzas in the Epilogue which, in its turn, repeats, in a shortened form, the structure of the elegy. In Memoriam, Tennyson himself points out, "begins with a funeral and ends with a marriage - begins with death and ends with promise of new life." The Epilogue begins with Hallam's death and ends with his life in God:

$O$ true and tried, so well and long,

Demand not thou a marriage lay;

In that it is marriage day

Is music more than any song.

Nor have I felt so much of bliss

Since first he told me that he loved

A daughter of our huuse; nor proved

Since that dark day a day like this;

Tho' 1 since then have number'd o'er

Some trice three years: thsy werit and came

Remade the blood and changed the frame,

And yet is love not less, but more;

No longer caring to embalm 
In dying songs a dead regref,

But like a statue solid-set, And moulded in colossa! calm.

Regret is dead, but love is more

Than in the summers that are flown,

For I myself with these have grown

To something greater than before;

Wich makes appear the songs I made

As echoes out of weaker times,

As half but idle brawling rhymes,

To sport of random sun and shade. (II. 1-24)

Whereof the man, that with me trod

This planet, was a noble type

Appearing ere the times were ripe,

That friend of mine who lives in God, (II. 137-40)

Within this framework, the bride is first seen agains a background suggestive of death and then pregnant with life:

Now waiting to be made a wife

Her feet, my darling, on the dead;

Their pensive tablets round her head,

And the most living words of life (II. 49-52)

And rise, $O$ Moon ...

And touch with shade the bridal doors

With tender gloom the roof, the wall;

And breaking let the splendour fall

To spangle all the happy shores

By wich they rest, and ocean sounds, And, star and system rolling past,

A soul shall draw from out the vast

And strike his being into bounds,

And, moved thro' life of lower phase

Result in man be born and think,

And act and love, (11. 109, 117.27)

Considering, therefore, the predominance of the image of the widow in the first half of the poem (lyrics written during the first two years after Hallam's death) and the predominance of the image of the bride in the second half (at first closely related to the poet's sorrow and then detached from it;, we have come to realize that this set of images is one of the most important metaphors of life and death throughout the elegy. Wthout them the conclusion of 
In Memoriam would be neither apropriate nor epitomic as it is.

\section{REFERENCES}

1 ANDERSON. George K. \& BUCKEL. William E., eds. The literatare of England. Atlanta, Seott, Foresman, 1968, v. 2.

2 RiCks, Christopher. Tennysan. New York, Collier, 1972.

3. SINFIEL.D, Alnn. The langange of Tennyson'a In Memarian. Oxford, Blackwell, 1971. $223 \mathrm{p}$.

4 STEANE, J. B. Tennyzon. New York, Areo, 1969. 169 p.

5 TFinNiSON, Alfred. In Memoriem. Ed. Robert Ross. New York, Nortan, 1973. 261 p.

6 WILLFY. Basil. More Nineteenth Century studies: a group of honest doubters. New York. Harper Row, 1966. 